\title{
Energy Recovery from Municipal Solid Waste in Oujda city (Morocco)
}

\author{
Mohammed Saghir ${ }^{1, *}$, Youssef Naimi ${ }^{1}$, Laila Laasri ${ }^{2}$, Mohamed Tahiri $^{3}$ \\ ${ }^{1}$ Laboratory of Physical Chemistry of Materials, Faculty of Sciences Ben M'Sik, University of Hassan II Casablanca, B.P. \\ 7955, Casablanca, Morocco \\ ${ }^{2}$ Laboratory of Chemistry Physics Catalysis and Environment, Faculty of Sciences Ben M'Sik, University of Hassan II \\ Casablanca, B.P. 7955, Casablanca, Morocco \\ ${ }^{3}$ Laboratory Interfaces, Materials and Environment, Faculty of Science Ain Chock, University of Hassan II Casablanca, B. P \\ 5366, Casablanca, Morocco
}

Received 24 November 2018; Accepted 10 March 2019

\begin{abstract}
The generation of Municipal Solid Waste (MSW) is inevitable. With population growth year after year and the increase in the standard of living, the quantities of waste are increasing exponentially and their efficient management has become a priority to municipal authorities worldwide. The Moroccan government has recognized the importance of effective sustainable resource management and the implementation of a national strategy as waste management. In Morocco, the Secretariat of State for Sustainable Development and the Ministry of the Interior have developed a waste management strategy called the National Household Waste Management Program (PNDM), which was implemented with the support of the World Bank, which targets for the next few years the quantitative objectives of waste collection (90\% in 2020), the implementation of controlled landfills and the development of waste sorting, recycling and valorization. Waste energy recovery is the most optimal management solution that not only eliminates the large quantities of waste produced each day but also creates the energy needed for a constantly growing population. The objective of this research work is to assess the municipal solid waste potential for electrical and thermal energy generation and biogas production using three modes of energy recovery (combustion, gasification and anaerobic digestion) in Oujda city (Morocco). The maximum electric load generated is $177.39 \mathrm{GWh}$ from waste gasification with electrical efficiencies of $17.3 \%$. Whereas for thermal energy, a maximum value of $277.17 \mathrm{GWh}$ is generated by direct combustion of MSW. For anaerobic digestion, the maximum potential methane generation capacity is $2.44106 \mathrm{~m} 3 /$ year in 2014 .
\end{abstract}

Keywords: Municipal Solid Waste; Energy recovery; Combustion; Gasification; Anaerobic digestion; Oujda city

\section{Introduction}

Every day, the human activity produces more than 10 billion kilos of municipal solid waste or approximately between 120 tonnes of waste per second. M. Elsen and al. estimates an increase of $40 \%$ in 2020 of the quantity of waste in the world [1]. Thus the management and recovery of waste are necessary for every country.

The quantity of municipal solid waste (MSW) generated, actually, in Morocco, totaled 6.98 million tonnes a year, 5.51 million tonnes in urban zones mean of 0.76 $\mathrm{kg} /$ inhabitant/day and 1.47 million tonnes in rural areas with a mean of $0.3 \mathrm{~kg} /$ inhabitant/day. These quantities will continue to increase from 6.98 million tonnes in 2018 to about 9.3 million tonnes a year in 2030[2].

To deal with this situation, the Moroccan government, in 2006, provides a first law 28-00 on solid waste management and opted for a gradual transformation by launching, in 2007, a 15- years program (National Municipal Solid Waste Management Program (PNDM)) with support from the World Bank. This approach has substantially improved the municipal solid waste management system which has become more efficient than ever before. Thusit has been

\footnotetext{
*E-mail address: energiessaghir@gmail.com

ISSN: $1791-2377$ @ 2019 Eastern Macedonia and Thrace Institute of Technology. All rights reserved. doi:10.25103/jestr.121.16
}

registered a waste collection rate of more than $85 \%$ in the majority of operational areas by company agents, this rate will reach $90 \%$ by 2020 according to the objectives of the PNDM. Energy recovery from MSW appears as an interesting solution to solve the problem of multiplication of waste, but also it responds to energy and climate challenges that countries are facing around the world.

The Moroccan strategy for the promotion of renewable energy sets up an objective of increasing the part of the renewable energy at $42 \%$ of the electric balance sheet in 2020. This objective can easily be achieved by introducing the recovered energy from municipal solid waste, not only to align with the national strategy but also to reduce the effects of global warming.

The objective of this research work is to assess the municipal solid waste potential for electrical and thermal energy generation and biogas production using three recovery processes (combustion, gasification and anaerobic digestion) in Oujda city (Morocco).

\section{Strategy of municipal solid waste management in Morocco}

Municipal solid waste management in Morocco focused on "clean-up" only and paid little attention and resources to waste disposal. This situation had significant negative economic, environmental and social consequences. In fact, 
the cost of environmental degradation was equivalent to $0.5 \%$ of GDP in 2000 and decreased in 2014 to $0.26 \%$ according to the World Bank Group Report of January 2017 [3]. This improvement is due to the new strategy adopted by the Moroccan government for the management of municipal solid waste since 2006 by the promulgation of the first law 28-00 on the management and disposal of waste reforming the waste sector.

In 2008, the government launched a three-phase, 15-year National Municipal Solid Waste Program (PNDM) with the support of the World Bank. These phases are:

Phase 1: 2008-2012, start-up; phase 2: 2013-2017, increased capacity; phase 3: 2018-2030, roll-out throughout the country. Its goals were set out as follows:

- To ensure the collection and the cleaning of municipal solid waste to reach a rate of collection of $90 \%$ in 2020 .

- $\quad$ Rehabilitate all old landfills $100 \%$ by 2020 .

- To develop the sector of "tri-recyclingvalorization", with pilot actions of sorting, to reach a rate of $20 \%$ of recycling in 2020 .

- To train and sensitize all the actors concerned with the problems of waste.

Currently, the majority of the great urban areas have new controlled landfills and others are in the course of construction. The overall cost of PNDM is estimated at close to 40 billion $\mathrm{DH}$, distributed as follows [4]:

- Collection and cleaning: $72 \%$.

- Construction and exploitation of controlled landfills: $14.6 \%$.

- Rehabilitation and closure of wild dumps: $6.3 \%$.

- $\quad$ Sorting, recycling and recovery: $1.8 \%$.

- Communication, raising awareness and training: $1.8 \%$.

The collection of municipal solid waste is the responsibility of urban municipalities. However, some large cities have delegated waste management to private companies.

The average composition of Moroccan municipal solid waste is represented in figure 1.

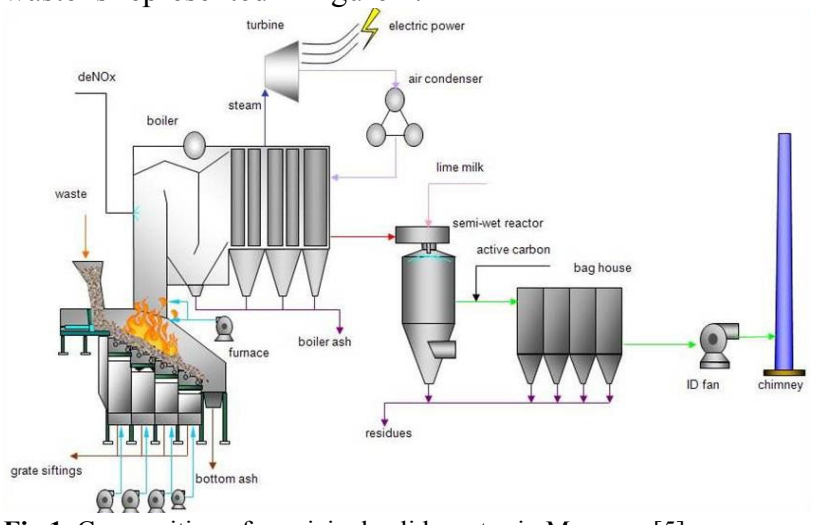

Fig.1. Composition of municipal solid wastes in Morocco [5]

\section{Production of energy by municipal solid waste}

Various types of technologies are studied to produce energy from waste: Direct combustion, gasification, production and valorization of biogas.

\subsection{Direct combustion of waste for energy production} Direct combustion is used as the main process to treat municipal solid waste and also provides electricity as a supplementary function [6]. Direct combustion of municipal solid waste in specific furnaces produces heat, which is used for heating and electricity generation. A direct combustion municipal solid waste system (Figure 2) consists of a combustion furnace, a boiler to produce heat, and a flue gas treatment system to eliminate the harmful effects of toxic gases. The steam generated by the combustion system boiler is used for heating, domestic hot water or to produce electricity from turbines.

The calorific value of municipal solid waste depends on the content of organic matter and moisture in the waste. On average, municipal solid waste has a heating value of around $13000 \mathrm{~kJ} / \mathrm{kg}$ [8]. Direct waste combustion plants for energy production have an electrical efficiency of $15.3 \%$ and a thermal efficiency of $42.5 \%$ [9].

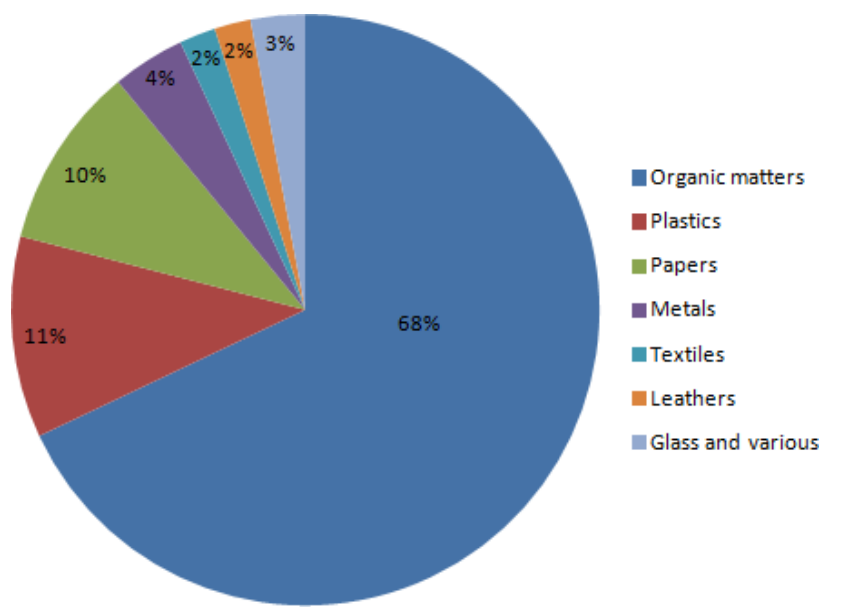

Fig. 2. Direct combustion of waste for energy production [7]

\subsection{Energy production by gasification of municipal} solid waste

Waste gasification is a thermal process that occurs at temperatures generally between 900 and $1200^{\circ} \mathrm{C}$ in the presence of a small amount of oxygen, this process requires an external thermal energy source for gasification reactions (endothermic reaction) [10]. Thermochemical gasification reactions occur in oxygen deficiency (between 30 and 50\% of stoichiometric demand) in order to avoid total combustion of the solid in order to produce syngas [11]. The gas produced by gasification is called synthesis gas, at a low calorific value than about 4 to $6 \mathrm{MJ} / \mathrm{m}^{3}$ [12] can be burned directly or used as fuel for internal combustion engines. The gas produced (synthesis gas) can be used in the manufacture of chemicals [12], and can also be converted into liquid hydrocarbons of various forms. The advantage of gasification is a higher electrical efficiency compared to combustion. In a combined cycle gas thermal power plant, the electrical efficiency is increased and the steam temperature decreases. The thermal energy produced by gasification is lower than that produced by direct combustion. The gasification process is used for electricity production [13, 14]. Gasification plants (figure 3) have a net electrical efficiency of $27.2 \%$ and a net thermal efficiency of $24.5 \%$ [9]. 
Mohammed Saghir, Youssef Naimi, Laila Laasri, Mohamed Tahiri/

Journal of Engineering Science and Technology Review 12 (1) (2019) 137 - 142

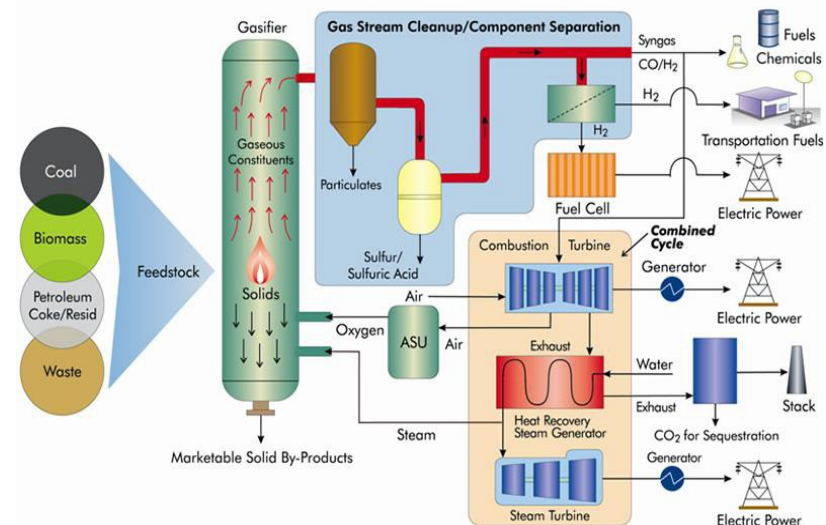

Fig.3. Gasification system (Gasifier) [15]

The gas produced by the gasification process (synthesis gas) contains various compounds: halogens, alkaline compounds, tars and heavy metals. Before using synthesis gas in electrical systems, these compounds must be removed.

\subsection{Quantification of energy by direct combustion and} gasification of municipal solid waste

There are several empirical equations for calculating the heating values of a substance. There are two methods for determining the heating values: the open calorimeter and oxygen bomb calorimeter. Researchers have developed a mathematical model to calculate the low heating value of municipal solid waste. This model (Eq.1) is expressed as follows [16]:

$\mathrm{LHV}=23(\mathrm{~F}+3.6 \mathrm{PA})+160 \mathrm{PL}$

In which (LHV) is the low heating value of municipal solid waste $(\mathrm{Btu} / \mathrm{Ib}),(\mathrm{PL})$ is percentage by weight of plastic in MSW, $(\mathrm{F})$ is percentage by weight of food in MSW and (PA) is percentage by weight of paper in MSW.

To quantify energy production, the Waste-To-Energy plant generates steam to a standard power plant with a temperature of $120^{\circ} \mathrm{C}$ and a pressure of $135 \mathrm{kPa}$ to produce electrical and thermal energy. The heating values of municipal solid waste compounds are (table 1):

Table 1. Heating values of municipal solid waste compounds [17]

\begin{tabular}{c|c}
\hline $\begin{array}{c}\text { Municipal solid waste } \\
\text { compounds }\end{array}$ & Heating value (kJ/kg) \\
\hline Iron & 420 \\
Metal & 544 \\
Glass & 628 \\
Water & 2636 \\
Combustibles (paper, plastics, & 18400 \\
textiles, wood ) & \\
\hline
\end{tabular}

Another more sophisticated model and it are experimentally validated by the researchers (Eq.1) allows calculating the heating value of MSW:

$$
\begin{aligned}
& \mathrm{HV}_{\mathrm{MSW}}=\mathrm{HV}_{\text {comb }} \mathrm{X}_{\text {comb }}-\mathrm{HV}_{\mathrm{H}_{2} \mathrm{O}} \mathrm{X}_{\mathrm{H}_{2} \mathrm{O}}-\mathrm{HV}_{\text {glass }} \mathrm{X}_{\text {glass }}- \\
& \mathrm{HV}_{\text {metal }} \mathrm{X}_{\text {metal }}
\end{aligned}
$$

Where:

- $H V_{M S W}(\mathrm{~kJ} / \mathrm{kg})$ : The heating value of municipal solid waste;
- $H V_{\text {comb }}(\mathrm{kJ} / \mathrm{kg})$ : The heating value of combustibles;

- $H V_{\mathrm{H}_{2} \mathrm{O}}(\mathrm{kJ} / \mathrm{kg}):$ Heat loss of water in MSW;

- $H V_{\text {glass }}(\mathrm{kJ} / \mathrm{kg})$ : Heat loss of glass in MSW;

- $H V_{\text {metal }}(\mathrm{kJ} / \mathrm{kg})$ : Heat loss of metal in MSW;

- $X_{\text {comb }}$ : The fraction of combustible matter in MSW;

- $X_{\mathrm{H}_{2} \mathrm{O}}$ : The fraction of water in MS;

- $X_{\text {glass }}$ : The fraction of glass in MSW;

- $X_{\text {metal }}$ : The fraction of metal in MSW;

So by substituting the numerical values for the calorific value of the waste compounds in model 2, we find (Eq.3):

$\mathrm{HV}_{\mathrm{MSW}}=18400 \mathrm{X}_{\mathrm{comb}}-2636 \mathrm{X}_{\mathrm{H}_{2} \mathrm{O}}-628 \mathrm{X}_{\text {glass }}-$ $544 \mathrm{X}_{\text {metal }}$

Where

$H V_{M S W}$ in $(\mathrm{kJ} / \mathrm{kg})$

Wet materials must be removed to improve combustion efficiency and maximize energy production per tonne of MSW. The steam cycle option is the most suitable for gasification, and it does not require pre-treatment of the gas, as the boiler burns all combustible products [18]. The electrical efficiency of a gasification plant is about $27.2 \%$ and that of the combustion plant is about $15.3 \%$ [9].

The steam cycle is the simplest option for energy recovery. It does not need gas pre-treatment, because tar is burned in the combustor and cannot damage the boiler [18]. The electrical efficiency of gasification-steam cycle plant is about $27.2 \%$, and electrical efficiency of the combustionsteam plant which is about $15.3 \%$ [9].

Then, the production of electrical energy and thermal energy by gasification-steam cycle plant or combustionsteam plant is calculated by the following equation (Eq. 4) [19]:

$\mathrm{E}(\mathrm{kJ})=\mathrm{M} * \mathrm{HV}_{\mathrm{MSW}} * \gamma$

Where:

- $E(k J)$ : Production of electrical energy and thermal energy;

- $\quad M(k g)$ : Quantity of municipal solid waste;

- $H V M S W(\mathrm{~kJ} / \mathrm{kg})$ : The heating value of municipal solid waste;

- $\quad \gamma$ : Efficiency of gasification plant or combustion plant;

3.4. Energy production by anaerobic digestion of municipal solid waste

Anaerobic digestion, or methanisation, is the natural process of degrading organic matter in the absence of oxygen. The main advantage of anaerobic digestion is that almost all of the degraded organic matter is in the form of biogas. Different micro-organisms transform complex organic substrates into simple molecules (monomers: acids, alcohols), then into biogas, contains from $45 \%$ to $70 \%$ methane [20], that can be recovered in the form of energy. The anaerobic digestion process takes place in several stages, with bacteria adapted to each stage, just like food digestion: (1) Hydrolysis and acidogenesis;

Acetogenesis; (3) Methanogenesis [21].

The degradation of organic waste in landfills produces biogas, which is composed mainly of methane and carbon dioxide [22]. Methane is the main gas for global warming. 
The extraction and use of methane from landfills not only benefits the environment by mitigating climate change, but also for the production of heat and electricity [23]. Biogas can be used to produce heat, electricity or both (cogeneration). In addition, it can also be injected into natural gas networks or used as a biofuel [24]. The energy content of biogas depends mainly on its methane content, so the biogas becomes combustible when it contains $25 \%$ of the methane. The energy value of biogas at $60 \%$ of $\mathrm{CH}_{4}$ is $2.16^{*} 10^{4} \mathrm{~kJ} / \mathrm{m}^{3}[25]$.

Landfill gas can be used directly in gas boilers and most internal combustion engines, while gas turbines and microturbines will require a treatment step by biological purifiers to remove siloxane and hydrogen sulfide [26].

The Biogas-to-CHP (combined heat and power) plant is the most widely used system in the world. The electricity generated by the Biogas-to-CHP system is fed into the electricity grid. The electrical and thermal efficiencies of different Biogas- to-CHP systems are presented in Table 2 [27].

Table 2. Efficiency and electricity input for CHP generation from biogas [27, 28, 29 and 30]

\begin{tabular}{l|l|l}
\hline & $\begin{array}{l}\text { CHP electrical } \\
\text { efficiency }\end{array}$ & $\begin{array}{l}\text { CHP thermal } \\
\text { efficiency }\end{array}$ \\
\hline $\begin{array}{l}\text { Small-scale biogas plant } \\
(\%)\end{array}$ & 33 & 50 \\
$\begin{array}{l}\text { Large-scale biogas plant } \\
(\%)\end{array}$ & 40 & 48 \\
\hline
\end{tabular}

Biogas can be transformed into biomethane after a purification step to leave $97 \%$ methane $\left(\mathrm{CH}_{4}\right)$ in the gas. Biomethane can be used as a fuel or injected into the natural gas grid [31].

Several types of mathematical models exist to calculate the production of biogas. They are generally based on decomposition kinetics of zero, of first order and second order. Others are of digital nature and have much precision, but their use requires several inputs that are not always at the disposal of managers [32].

First-order models are the most widely used in the world because of the compromise between accuracy and ease of use [33]. Among the first-order models, we distinguish the LandGEM model (Landfill Gas Emissions Model) [32].

The Land-GEM model is an estimation model that estimates the production rates of methane, carbon dioxide, non-methane organic compounds (NMOCs) and air pollutants from municipal landfills. The model is represented by the equation (Eq.5) [34]:

$\mathrm{Q}_{\mathrm{CH}_{4}}=\sum_{\mathrm{i}=1}^{\mathrm{n}} \sum_{\mathrm{j}=0.1}^{1} \mathrm{~kL}_{0}\left(\frac{\mathrm{M}_{\mathrm{i}}}{10}\right) \mathrm{e}^{-\mathrm{kt} \mathrm{t}_{\mathrm{i}, \mathrm{j}}}$

\section{Where:}

- $Q_{\mathrm{CH}_{4}}\left(m^{3} \cdot\right.$ year $\left.^{-1}\right)$ : Annual methane generation in the year of the calculation;

- $i$ : One-year time increments;

- $n$ : Number of years calculated (year of the calculation - initial year of waste acceptance);

- $j$ : 0.1 year time increment (cutting the year into tenth);

- $k\left(\right.$ year $\left.^{-1}\right)$ : Methane generation rate;

- $L_{0}\left(\mathrm{~m}^{3} \cdot \mathrm{Mg}^{-1}\right)$ : Potential methane generation capacity;

- $M_{i}(M g)$ : Mass of waste accepted in the $\mathrm{i}^{\text {th }}$ year;
- $t_{i, j}$ : Age of the $\mathrm{j}^{\text {th }}$ section of waste mass $\mathrm{M}_{\mathrm{i}}$ accepted in the $\mathrm{i}^{\text {th }}$ year;

LandGEM offers the value of constant $k$ and the potential value of methane production $\mathrm{L}_{0}$, both CAA (Clean Air Act) and the other for $\mathrm{AP}_{42}$ standards. It is recommended to use standard $\mathrm{AP}_{42}$ standard values for landfills.

The default methane content in the landfill gas is $50 \%$, which are both the industry standard value and the default value recommended by LMOP (Landfill Methane Outreach Program) [35].

\section{Assessment of the energy recovery potential from municipal solid waste in Oujda city}

\subsection{Description of the study area - Oujda city}

The city of Oujda is located in the northeast of Morocco, in the Oriental Region, the third largest region of the Kingdom. The city of Oujda enjoys a Mediterranean climate with a mild to cold and rainy winter and a warm summer. The city of Oujda has a population of 494252 , according to the latest general population census in 2014 [36]. The economy of Oujda is mainly oriented towards agriculture, mining, trade and crafts, but also presents interesting energy assets. Population growth has a direct influence on the waste sector, but an average of 143454 tonnes [37] of waste is collected every year in Oujda within 2011 to 2014 .

\subsection{Evolution of the quantity of municipal solid waste in Oujda}

The controlled landfill of Oujda is located south of the city about $10 \mathrm{~km}$, in a non-agricultural zone with a very clayey (impermeable) soil and an area of 130 ha, this landfill entered the operating phase in 2005 [37], benefiting from several modern treatment technologies (selective sorting, recycling, waste treatment, leachate management and treatment, energy conversion station, biogas pumping station).

The landfill is fenced and has a weight scale, an operating building, a meteorological station, a clogging of the base and also a drainage system for leachate treatment and biogas capture. In particular, vertical wells for biogas collection were set up, allowing the collection of biogas to achieve energy recovery from a biogas cogeneration plant, totaling an installed electrical power of the order of 6.9 $\mathrm{MW}_{\mathrm{el}}$. The electricity generated is then injected into the distribution network, for a total of $19.000 \mathrm{MW}_{\mathrm{el}}$ per year [38].

Table 3. Tonnage (in tonnes) of municipal solid waste in Oujda 2011-2014 [38, 5]

\begin{tabular}{c|c|c|c|c}
\hline Years & 2011 & 2012 & 2013 & 2014 \\
Tonnage (t) & 134828 & 139801 & 146313 & 152873 \\
\cline { 2 - 5 } $\begin{array}{c}\text { Fermentable } \\
\text { waste } \\
\text { Moisture }\end{array}$ & \multicolumn{3}{|c}{$73,25 \%$} \\
\hline
\end{tabular}

Table 3 shows the annual amount of waste collected from 2011 to 2014 in the city of Oujda, as well as the percentage of fermentable waste in MSW.

4.3. Direct combustion of municipal solid waste for 


\section{energy production in Oujda}

The electricity and thermal energy production from municipal solid waste can be calculated knowing the calorific power and the organic composition. A calculation is made to evaluate the amount of energy recovery for MSW if the waste is incinerated.

Table 4 shows the results of the evaluation of the electricity and thermal energy production by direct combustion for the city of Oujda. We observe the growth of energy (electricity and thermal energy) over the years, as well as electricity production in 2014 is 99.78 $\mathrm{GWh} /$ year and thermal energy reaches $277.17 \mathrm{GWh} /$ year.

For the direct combustion plant, the production of thermal energy is higher than that of electrical energy.

Table 4. Production of electricity and thermal energy by direct combustion of municipal solid waste in Oujda

\begin{tabular}{l|l|l|l|l}
\hline & 2011 & 2012 & 2013 & 2014 \\
\hline $\begin{array}{l}\text { Electricity (GWh) } \\
\text { Thermal energy }\end{array}$ & 88.00 & 91.25 & 95.50 & 99.78 \\
(GWh) & & 253.47 & 265.28 & 277.17 \\
& & & & \\
\hline
\end{tabular}

4.4. Gasification of municipal solid waste for energy production in Oujda

According to the composition of household waste in Morocco and energy efficiencies of gasification, as well as equations 3 and 4 , a calculation is made to evaluate the amount of energy recovery for MSW if the waste is gasified.

The obtained results (Table 5) shows that the production of electricity and thermal energy increase gradually over the years with a relatively higher electricity production than thermal energy unlike the results found using MSW combustion plant.

\subsection{Energy production through anaerobic digestion of municipal solid waste in Oujda}

The application of the LandGEM Model (equation 5) allowed estimating the quantities of biogas produced by the landfill (table 6).

Table 5. Production of electricity and thermal energy by gasification of municipal solid waste in Oujda

\begin{tabular}{l|l|l|l|l}
\hline & 2011 & 2012 & 2013 & 2014 \\
\hline $\begin{array}{l}\text { Electricity (GWh) } \\
\text { Thermal energy } \\
\text { (GWh) }\end{array}$ & 156.45 & 162.22 & 169.78 & 177.39 \\
\hline
\end{tabular}

The parameter, $\mathrm{k}$, determines the rate of methane generation for the waste mass in the landfill. The higher the $\mathrm{k}$ value, the faster the methane production rate increases over time [34]. In the case of the Oujda controlled landfill $\mathrm{k}=0.05$ year $^{-1}$ used.

The potential methane production capacity $\mathrm{L}_{0}$ depends solely on the type and composition of the waste placed in the landfill. The higher the cellulose contents of the waste, the higher the value of $\mathrm{L}_{0}$ [34]. In the case of Oujda controlled landfill $\mathrm{L}_{0}=170 \mathrm{~m}^{3} / \mathrm{Mg}$ is used.

The lower calorific value of methane is $35.8 \mathrm{MJ} / \mathrm{m}^{3}$ [39] and according to table 2, the production of electricity and thermal energy by a small biogas plant for fermentable waste in Oujda:
Table 6. Values of tonnage of fermentable waste stored (ton), biogas production $\left(\mathrm{m}^{3}\right)$, and methane production $\left(\mathrm{m}^{3}\right)$ for each year from 2011 to 2014 in Oujda

\begin{tabular}{l|l|l|l|l}
\hline & 2011 & 2012 & 2013 & 2014 \\
\hline $\begin{array}{l}\text { Fermentable waste } \\
\text { stored (ton) }\end{array}$ & & 102404.23 & 107174.27 & 111979.47 \\
$\begin{array}{l}\left.\text { Biogas production } \mathbf{( m}^{3}\right) \\
\begin{array}{l}\text { Methane production } \\
\left(\mathbf{m}^{3} / \text { year) }\right.\end{array}\end{array}$ & 0 & $1.6410^{6}$ & $3.2610^{6}$ & $4.8810^{6}$ \\
\hline
\end{tabular}

Table 7. Production of electricity and thermal energy by a small biogas plant system in Oujda

\begin{tabular}{|c|c|c|c|c|}
\hline & 2011 & 2012 & 2013 & 2014 \\
\hline $\begin{array}{l}\text { CHP electrical energy } \\
\text { (GWh) }\end{array}$ & 0 & 2.70 & 5.30 & 8.00 \\
\hline $\begin{array}{l}\text { CHP thermal energy } \\
\text { (GWh) }\end{array}$ & 0 & 4.10 & 8.10 & 12.15 \\
\hline
\end{tabular}

The results shown in table 7 , shows the evolution of the production of electrical energy and thermal energy by a biogas-to-CHP plant of fermentable waste in Oujda. Energy production is increasing over the years. The electricity production in 2014 is $8 \mathrm{GWh}$ and thermal energy is $12.15 \mathrm{GWh}$. So for small-scale biogas plants, thermal energy production is higher than electricity production.

\section{Conclusions and recommendations}

According to the obtained results based on the calculations of the electricity and thermal energy produced by combustion, gasification and aerobic digestion of MSW of Oujda city, we can conclude that the energy recovery of MSW can make a significant contribution to the national energy balance. Combustion, as modeled here, would have the highest gate fee and the greatest capital cost. A market for the thermal product is extremely important in terms of gate fee and greenhouse gas production. In theory, gasification is a more suitable technology for Morocco where the market for the thermal product is difficult; however, the constraint with gasification of MSW is the technology which is not yet proven at commercial scale.

Biogas technology requires significantly fewer investment costs than the thermal conversion technologies (incineration and gasification) and have smaller gate fees. It should be noted that biogas production is not an alternative to incineration or gasification because biogas is produced from the organic fraction of MSW and thermal treatment is applied to the non- organic, nonrecyclable fraction.

Converting municipal solid waste (MSW) into energy has the environmental benefit of reducing greenhouse gases to stop global warming, preventing contamination of water and air, and reducing dependence on oil and other fossil fuels for energy production.

This is an Open Access article distributed under the terms of the Creative Commons Attribution License

\section{References}

[1] M. Elsen and M. Vierin, report: Waste Management in Frenchspeaking World, Parliamentary Assembly of the Frenchspeaking World, Morocco, 2006.
[2] Ministry of Energy, Mines, Water and Environment, Project Nationally Appropriate Mitigation Actions-NAMA, Mechanobiological treatment (TMB) coupled to co- incineration, 
Mohammed Saghir, Youssef Naimi, Laila Laasri, Mohamed Tahiri/

\section{Journal of Engineering Science and Technology Review 12 (1) (2019) 137 - 142}

Morocco, 2015.

[3] L. Croitoru and M. Sarraf, Le Coût de la Dégradation de l'Environnement au Maroc,

World Bank Group Report Number 105633-MA, 2017.

[4] Ministry of the Interior website, National Household Waste Management Program (PNDM), Morocco, 2017 (www.pncl.gov.ma/fr/grandchantiers/Pages/PNDM.aspx).

[5] French Chamber of Commerce and Industry of Morocco, Analysis and potential of the market: The market for water and waste treatment in Morocco, 2015.

[6 C. Liamsanguan and S. H. Gheewala, "Environmental assessment of energy production from municipal solid waste incineration," The International Journal of Life Cycle Assessment, vol. 12, pp. 529-536, Nov. 2007.

[7] http://www.epem.gr/waste-c-control/database/html/WtE-01.htm

[8] L.D. Smoot and P.J. Smith, Coal Combustion and Gasification, Plenum Press, New York, 1985.

[9] J. D. Murphy and E. McKeogh, "Technical, economic and environmental analysis of energy production from municipal solid waste," Renewable Energy, vol. 29, pp. 1043- 1057, Jun. 2004.

[10] U. Arena, "Process and technological aspects of municipal solid waste gasification, A review," Waste Management, vol. 32, pp. 625-639, Apr. 2012.

[11] A. Deydier, Modélisation d'un réacteur de gazéification à lit fixe, Ph.D. Thesis,

University of Pau and Pays de l'Adour (UPPA), France, 2012.

[12] P. McKendry, "Energy production from biomass (part 2): conversion technologies, Bioresource Technology," vol. 83, pp. 47-54, 2002.

[13] W.R. Niessen, C.H. Marks, R.E. Sommerlad, C. Dresser, Evaluation of Gasification and Novel Thermal Processes for the Treatment of Municipal Solid Waste, National Renewable Energy Laboratory NREL/TP-430-21612 UC Category: 1414 DE96013093, United States, 1996.

[14] IEA CADDET Centre for Renewable Energy, Advanced Thermal Conversion Technologies for Energy from Solid Waste: A Joint Report of the IEA Bioenergy Programme and the IEA CADDET Renewable Energy Technologies Programme, Oxfordshire, UK, 1998.

[15] R. Rodrigues, Coal gasification technologies to power generation in Brazil, Federal University of Pampa, Brazil, 2016.

[16] C. Dong, B. Jin and D. Li, Predicting the heating value of MSW with a feed forward neural network, Waste Management, vol. 23, pp. 103-106, 2003.

[17] N. J. Themelis, Y. H. Kim, and M. H. Brady, Energy recovery from New York City solid wastes, ISWA journal: Waste Management and Research, vol. 20, pp. 223-233, 2002.

[18] P. Quaak, H. Knoef, H. Stassen, Energy from biomass, World Bank technical paper Number 422, Energy series, 1999.

[19] Y. Naimi, M. Saghir, A. Cherqaoui, and B. Chatre, Energetic recovery of biomass in the region of Rabat (Morocco), International Journal of Hydrogen Energy, vol. 42, pp. 13961402, 2017.

[20] S. Rasi, Biogas composition and upgrading to biomethane, University of Jyväskylä, Finland, 2009.

[21] L. Anajji, Contribution à l'étude expérimentale de la biométhanisation de quelques déchets solides domestiques, $\mathrm{PhD}$ thesis, Cadi Ayyad University, Faculty of Science Semlalia Marrakech, Morocco, 1997.

[2] L. Meyer, S. Brinkman, L. Van Kesteren, L. Leprince-Ringuet and F. Van Boxmeer, Technical Support Unit for the Synthesis Report, Intergovernmental Panel on Climate Change, Geneva, Switzerland, 2015.

[23] Environmental Protection Agency, LFG Energy Project Development Handbook, Washington, United States, 2017.

[24] S. Bonnier, Etat de la valorisation du biogaz sur site de station d'épuration en France et

en Europe. Synthèses techniques en gestion de l'eau, AgroParisTech, France, 2008.

[25] Energy Information Administration (EIA), Biofuels: Ethanol and Biodiesel, Washington, United States, 2017.

[26] A. B. P. Suzuki, D. M. Fernandes, R. A. P. Faria, and T. C. M. Vidal, Biogas utilization in internal combustion engines, Brazilian Journal of Applied Technology in Agrarian Sciences, vol. 4, pp. 221-237, 2011.

[27] M. Pöschl, S. Ward, and P. Owende, Evaluation of energy efficiency of various biogas production and utilization pathways, Applied Energy, vol. 87, pp 3305-3321, 2010.

[28] B. Eder, H. Schulz, Biogas praxis, 3rd ed. Ökobuch Magnum, Staufen (Germany), 2006.

[29] C. Becker, H. Döhler, H. Eckel, N. Fröba, T. Georgieva, J. Grube and al, "Empirical values for biogas," 1st ed. Germany: Darmstadt, 2007.

[30] C. Walla and W. Schneeberger, The optimal size for biogas plants, Biomass and Bioenergy, vol. 32, pp. 551-557, 2008.

[31] D. Goulding and N. Power, Which is the preferable biogas utilization technology for anaerobic digestion of agricultural crops in Ireland: Biogas to CHP or biomethane as a transport fuel?, Renewable Energy, vol. 53, pp. 121-131, 2013.

[32] H. Kamalan, M. Sabour and N. Shariatmadari,"A Review on Available Landfill Gas Models," Journal of Environmental Science and Technology, vol. 4, pp. 79-92, 2011.

[33] H. Amini, R. Cont and A. Minca, Resilience to contagion in financial networks, Mathematical Finance, vol. 26, pp. 329-365, 2016

[34] A. Alexander, C. Burklin and A. Singleton, Landfill Gas Emissions Model (LandGEM) Version 3.02 User's Guide, Environmental Protection Agency, Number EPA-600/R- 05/047, United States, 2005.

[35] R. Pierson, Fact Sheet: Landfill Methane, Environmental and Energy Study Institute, United States, 2013.

[36] High Commission for Planning, Population légale des régions, provinces, préfectures, municipalités, arrondissements et communes du Royaume d'après les résultats du RGPH 2014, Morocco, (2014)

[37] M. Lyoubi and Z. Bellefiqh, Compte Rendu de la 5ème Rencontre à la Ville d'Oujda sous le thème : Les expériences dans la gestion des Déchets au Maghreb (Maroc et Tunisie), Moroccan Network of Urban Waste Management (REMAGDU) and German Society for International Cooperation (GIZ) GmbH, Morocco, 2013.

[38] Cleaner Energy Saving Mediterranean Cities project, Morocco: Municipality of Oujda Action Plan for Sustainable Energy (PAED), Company Hulla \& Co. Human Dynamics KG, Ministry of Energy, Mines, Water and Environment of Morocco, Municipality of Oujda, Company

"EnvirOconsult" and Company "Ide-e", EuropAid/132630/C/SER/MULTI, Morocco, 2015.

[39] L. Waldheim and T. Nilsson, Heating value of gases from biomass gasification, IEA Bioenergy Agreement subcommittee on Thermal Gasification of Biomass, Nyköping, Sweden, 2001 